\title{
Potensi Aktinomisetes Asal Tanah Perakaran Mangrove Segara Anakan Cilacap Sebagai Penghasil Anti-fungi Terhadap Candida albicans
}

\author{
Rifqi Aulia Akbar ${ }^{*}$, Dini Ryandini, Dyah Fitri Kusharyati
}

Faculty of Biology, Universitas Jenderal Soedirman, Purwokerto, Indonesia

*Corresponding author, email: rifqiauliaakbar@gmail.com

\section{ARTICLE INFO}

\section{Article history:}

Received 14/07/2017

Received in revised form 12/10/2017

Accepted 12/10/2017

\section{Keywords:}

Candida albicans

Actinomycetes

Antifungal

Mangrove root soil

DOI: $10.22146 / j t b b .26554$

\begin{abstract}
A B S T R A C T
Isolation of actinomycetes has been done from mangrove soil sample of Segara Anakan Cilacap. This research aimed to know the potency of actinomycetes as an antifungal producer, and to measure antifungal activity produced by actinomycetes based on diameter zone inhibition and to know the characteristic of the bioactive compound with Thin Layer Chromatography method. The result of the study has been isolated 24 actinomycetes isolates, 15 of them had potential as an antifungal producer, which inhibited the growth of Candida albicans. Period of fermentation significantly affected to the activity of the antifungal compound. The highest inhibitory zone was formed by an antifungal extract from actinomycetes $C$ with a range zone $19.7 \mathrm{~mm}$ in length at 14th days fermentation, which was extracted with ethyl acetate solvent $(1: 1 \mathrm{v} / \mathrm{v})$. The characteristic of a bioactive compound of the actinomycetes $C$ ha s a Rf value 0.5 in the solvent $n$ -butanol, acetic acid and water (3: 2: $1 \mathrm{v} / \mathrm{v} / \mathrm{v})$.
\end{abstract}

\section{Pendahuluan}

Aktinomisetes merupakan bakteri Gram positif berbentuk filamentus dan mampu membentuk spora. Dibandingkan dengan kelompok bakteri lain, aktinomisetes mengalami pembelahan kompleks dan dapat menghasilkan beragam senyawa bioaktif (Dewi, 2014). Kelompok utama dari ordo Actinomycetales adalah Actinoplanetes, Maduromycetes, Nocardioform, Actinomycetes dan Streptomycetes (Brown-Elliott et al., 2006).

Habitat utama aktinomisetes, terutama Streptomyces, adalah di tanah. Streptomyces menyusun kurang lebih $70 \%$ dari mikroorganisme yang ada di tanah (Rao, 2001). Streptomyces dapat diisolasi pada berbagai lingkungan, bahkan dari lingkungan yang tidak biasa (unusual environment). Salah satu contoh lingkungan yang dapat menjadi sumber isolat aktinomisetes adalah pada tanah ekosistem mangrove, salah satunya yaitu kawasan mangrove Segara Anakan Cilacap.

Aktinomisetes mempunyai kemampuan menghasilkan senyawa bioaktif berupa anti-fungi. Salah satu senyawa antifungi yang dihasilkan memiliki kemampuan untuk menghambat pertumbuhan Candida. Jamur Candida merupakan penyebab infeksi oportunis (Kandidiasis) pada manusia yang disebabkan oleh spesies $C$. albicans, $C$. tropicalis, C. parapsilosis, C. glabrata, C. gulliermondii, dan C. dubliniensis (Brooks et al., 2004). Kandidiasis menyerang rongga mulut, bibir vagina dan saluran pencernaan.

Penelitian ini bertujuan untuk mengeksplorasi aktinomisetes tanah dari perakaran mangrove di Segara Anakan Cilacap sebagai penghasil senyawa anti-fungi terhadap C. albicans.

\section{Bahan dan Cara Kerja}

\subsection{Isolasi Aktinomisetes}

Isolasi aktinomisetes dilakukan berdasarkan metode dari Wardana (2012). Sampel tanah diambil dari daerah rhizosfer tumbuhan Avicennia marina di kawasan mangrove Segara Anakan Cilacap, Jawa Tengah. Sampel tanah ditimbang sebanyak 1 gram dan dilakukan pengenceran berseri dalam larutan $\mathrm{NaCl}$ fisiologis hingga pengenceran $10^{-3}$. Dua pengenceran terakhir dari masing-masing sampel ditanam dengan metode tuang secara duplo pada medium Starch Casein Nitrate Agar (SCNA) dan diinkubasi selama 7 hari. 
Koloni yang tumbuh dimurnikan dengan teknik quadrant streak pada medium SCNA.

\subsection{Penapisan primer}

Penapisan primer dilakukan menggunakan metode gores setengah cawan berdasarkan Kang et al., (2010). Isolat yang memiliki ciri kenampakan koloni aktinomisetes digoreskan hingga memenuhi setengah dari permukaan medium PDA, kemudian diinkubasi selama 7 hari pada suhu ruang hingga terjadi sporulasi. Isolat $C$. albicans digoreskan tunggal dengan jarak $5 \mathrm{~mm}$ secara tegak lurus terhadap isolat aktinomisetes. Biakan diinkubasi selama 48 jam pada suhu ruang. Aktivitas anti-fungi diamati secara kualitatif dengan cara melihat jarak penghambatan pertumbuhan $C$. albicans terhadap koloni bakteri aktinomisetes. Isolat aktinomisetes yang menunjukkan aktivitas penghambatan tertinggi diseleksi lebih lanjut.

\subsection{Penapisan sekunder}

Penapisan sekunder dilakukan berdasarkan Oskay (2009). Isolat terpilih diperbanyak jumlahnya pada medium SCNA dengan metode streak kontinyu rapat dan diinkubasi selama 7 hari pada suhu ruang untuk dijadikan inokulum. Koloni yang tumbuh diambil 5 plug dengan cork borer dan ditumbuhkan pada medium SCNB $100 \mathrm{ml}$. Inkubasi dilakukan pada suhu ruang selama 7 hari. Filtrat bebas sel diperoleh dengan cara sentrifugasi pada kecepatan 8000 rpm selama 10 menit. Kertas cakram berukuran $6 \mathrm{~mm}$ ditetesi $20 \mu \mathrm{l}$ filtrat bebas untuk uji penghambatan terhadap $C$. albicans. Biakan diinkubasi pada suhu ruang selama 24 jam. Diameter zona hambat yang terbentuk diamati dan diukur diameternya dengan penggaris.

\subsection{Karakterisasi isolat Aktinomisetes}

Karakterisasi isolat aktinomisetes meliputi pengamatan secara morfologi dan penggunaan sumber karbon. Pengamatan morfologi meliputi pewarnaan Gram, warna miselium aerial, warna miselium substrat, bentuk koloni, tepi koloni, elevasi koloni, permukaan koloni dan ukuran koloni. Sumber karbon yang digunakan berupa glukosa, raffinosa, mannose, laktosa, arabinosa, sukrosa, fruktosa, xylosa, dan maltosa. Hasil karakterisasi dibandingkan dengan buku Bergey's Manual Determinative of Bacteriology Tahun 1994.

\subsection{Produksi senyawa anti-fungi}

Senyawa anti-fungi diproduksi menggunakan modifikasi metode Sharma dan Parihar (2010). Inokulum fermentasi berasal dari isolat aktinomisetes yang ditumbuhkan secara streak rapat pada medium SCNA dan diinkubasi selama 7 hari. Sebanyak 5 plug inokulum yang telah dilubangi dengan cork borer diinokulasi ke dalam $400 \mathrm{ml}$ medium Starch Casein Nitrate Broth (SCNB). Inkubasi dilakukan pada suhu ruang selama 7, 14 dan 21 hari. Filtrat bebas sel yang mengandung senyawa anti-fungi diperoleh dengan cara penyaringan menggunakan kertas saring Whatman.

\subsection{Ekstraksi senyawa anti-fungi}

Filtrat diekstraksi menggunakan pelarut etil-asetat dengan perbandingan antara filtrat dengan pelarut sebesar 1:1 (v/v) dan dilakukan pengulangan sebanyak 2 kali. Lapisan bagian atas yang mengandung senyawa anti-fungi diuapkan menggunakan alat rotatory evaporator pada suhu $70^{\circ} \mathrm{C}$ (titik didih pelarut) hingga didapatkan ekstrak kasar (Ayari et al., 2016).

\subsection{Uji aktivitas penghambatan ekstrak senyawa anti-fungi}

Uji aktivitas dilakukan dengan metode difusi kertas cakram berdasarkan modifikasi metode Purwantini dan Wahyuono (2004) serta Prakash et al. (2013). Ekstrak kasar sebanyak $20 \mu \mathrm{l}$ diteteskan ke dalam kertas cakram berdiameter $6 \mathrm{~mm}$ (Whatman No. 1) untuk uji aktivitas penghambatan terhadap $C$. albicans. Biakan kemudian diinkubasi pada suhu ruang selama 24 jam. Zona hambat yang terbentuk diamati dan diukur diameternya menggunakan penggaris.

\subsection{Karakterisasi senyawa anti-fungi}

Karakterisasi dilakukan dengan metode kromatografi lapis tipis (KLT) berdasarkan modifikasi metode Ayari et al. (2016). Sebanyak $10 \mu$ l ekstrak senyawa anti-fungi diteteskan pada lempeng kromatografi (TLC alumunium sheet silica gel $\left.60 F_{254}\right)$. Lempeng direndam dalam larutan eluen berupa campuran n-butanol, asam asetat dan akuades dengan perbandingan 3:2:1. Lempeng dikeringkan dalam oven pada suhu $80^{\circ} \mathrm{C}$ selama 2 jam. Lempeng kemudian diamati menggunakan UV Transilluminator dengan panjang gelombang $254 \mathrm{~nm}$ dan disemprot dengan larutan nynhidrin $(0,2 \%)$. Spot yang terbentuk diukur nilai Rf.

\section{Hasil}

\subsection{Isolasi Aktinomisetes dan skrining aktivitas anti-fungi}

Isolasi menggunakan medium selektif SCN menghasilkan 24 isolat yang diduga sebagai aktinomisetes berdasarkan ciri morfologi koloni berupa adanya miselium 


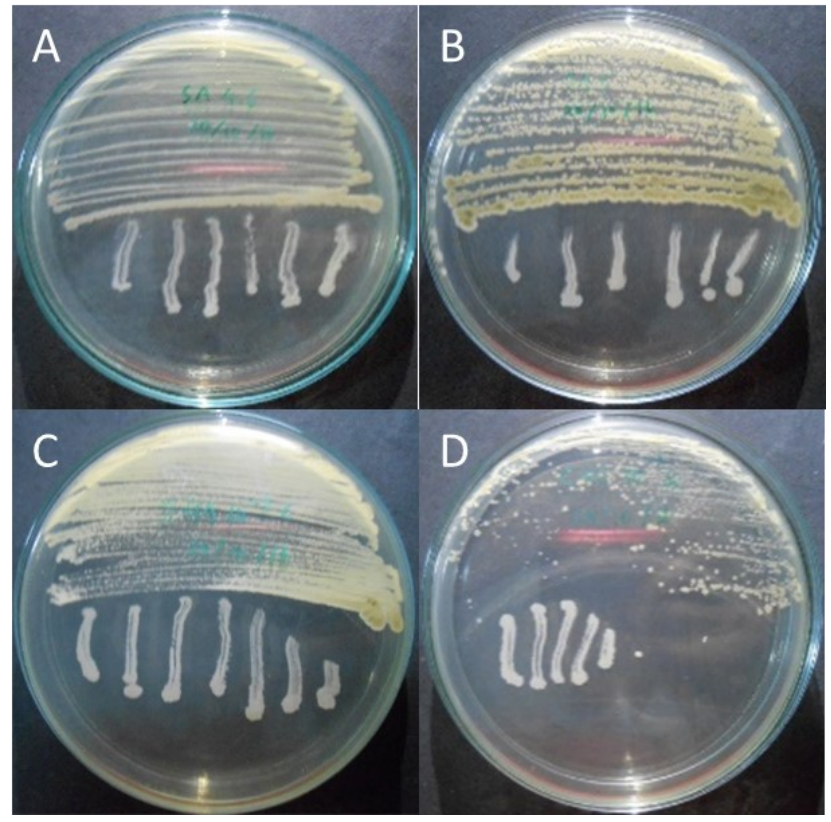

Gambar 1. Hasil Skrining Primer Aktivitas Anti-fungi Isolat Aktinomisetes. A (-), B (+), C (++), dan D (+++).

aerial dan substrat (Gambar 2). Setelah dilakukan skrining primer, ditemukan 15 isolat yang menunjukkan potensi sebagai penghasil senyawa anti-fungi, dan dipilih 1 isolat dengan aktivitas penghambatan tertinggi (Tabel 1, Gambar 1). Hasil skrining sekunder dari isolat $C$ juga menunjukkan adanya aktivitas anti-fungi membentuk zona hambat di sekitar kertas cakram dengan diameter $8 \mathrm{~mm}$.

Tabel 1. Pengamatan Skrining Primer.

\begin{tabular}{|c|c|c|}
\hline No. & Kode Isolat & Aktivitas Penghambatan \\
\hline 1 & A & ++ \\
\hline 2 & B & ++ \\
\hline 3 & C & +++ \\
\hline 4 & D & - \\
\hline 5 & $\mathrm{E}$ & + \\
\hline 6 & $\mathrm{~F}$ & + \\
\hline 7 & G & + \\
\hline 8 & $\mathrm{H}$ & ++ \\
\hline 9 & I & - \\
\hline 10 & J & + \\
\hline 11 & K & - \\
\hline 12 & $\mathrm{~L}$ & + \\
\hline 13 & M & + \\
\hline 14 & $\mathrm{~N}$ & - \\
\hline 15 & $\mathrm{O}$ & - \\
\hline 16 & $P$ & - \\
\hline 17 & $\mathrm{Q}$ & - \\
\hline 18 & $R$ & ++ \\
\hline 19 & S & + \\
\hline 20 & $\mathrm{~T}$ & - \\
\hline 21 & $u$ & ++ \\
\hline 22 & v & - \\
\hline 23 & W & + \\
\hline 24 & $x$ & ++ \\
\hline
\end{tabular}

Keterangan : $(-)=$ tidak berpotensi; $(+)=$ cukup berpotensi; $(++)=$ berpotensi; $(+++)=$ sangat berpotensi

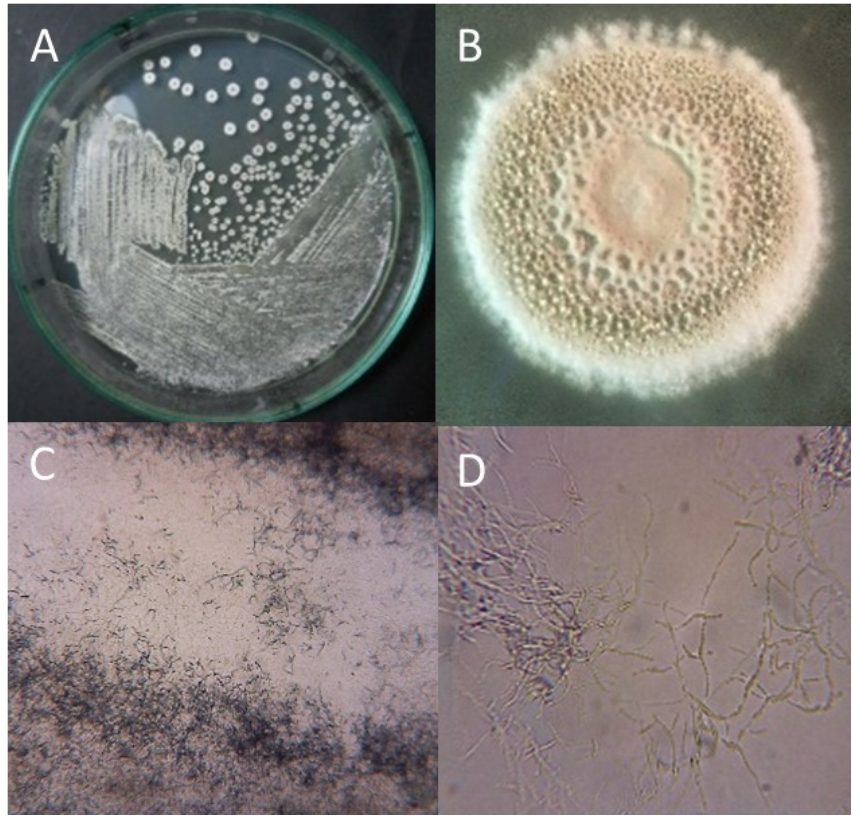

Gambar 2. Karakter Kultur (A), Morfologi Koloni (B), miselium substrat dan aerial (C), dan Tipe Rantai Spora (D) Isolat Aktinomisetes $\mathrm{C}$

3.2. Karakterisasi morfologi dan penggunaan sumber karbon isolat Aktinomisetes $\mathrm{C}$

Isolat Aktinomisetes C memiliki karakter dinding sel Gram positif, miselium substrat berwarna kuning muda, miselium aerial berwarna krem, bentuk koloni sirkuler, tepi koloni filiform, elevasi koloni raised, permukaan koloni powdery, ukuran koloni antara 4-6 $\mathrm{mm}$, memiliki tipe rantai spora straight (Gambar 2), dan kemampuan menggunakan sumber karbon yang dirangkum pada Tabel 2 .

Tabel 2. Penggunaan jenis sumber karbon oleh isolat Aktinomisetes

\begin{tabular}{cc}
\hline Jenis Gula & Penggunaan Sebagai Sumber Karbon \\
\hline Fruktosa & + \\
Sukrosa & - \\
Xylosa & + \\
Maltosa & + \\
Laktosa & + \\
Mannosa & + \\
Raffinosa & - \\
Arabinosa & + \\
Glukosa & + \\
\hline
\end{tabular}

3.3. Pengaruh periode waktu inkubasi terhadap aktivitas antifungi

Terdapat pengaruh periode waktu inkubasi terhadap aktivitas senyawa anti-fungi yang dihasilkan oleh aktinomisetes C (Gambar 3). Diameter zona hambat dari aktivitas ekstrak senyawa yang diperoleh dari ekstraksi medium fermentasi hari ke-7, 14 dan 21 berturut-turut sebesar $11.3 \mathrm{~mm}, 19,7 \mathrm{~mm}$, dan $11 \mathrm{~mm}$. Aktivitas penghambatan tertinggi ditunjukkan oleh ekstrak senyawa anti-fungi yang diperoleh dari ekstraksi medium fermentasi hari ke-14 menggunakan pelarut etil asetat (Gambar 4). 


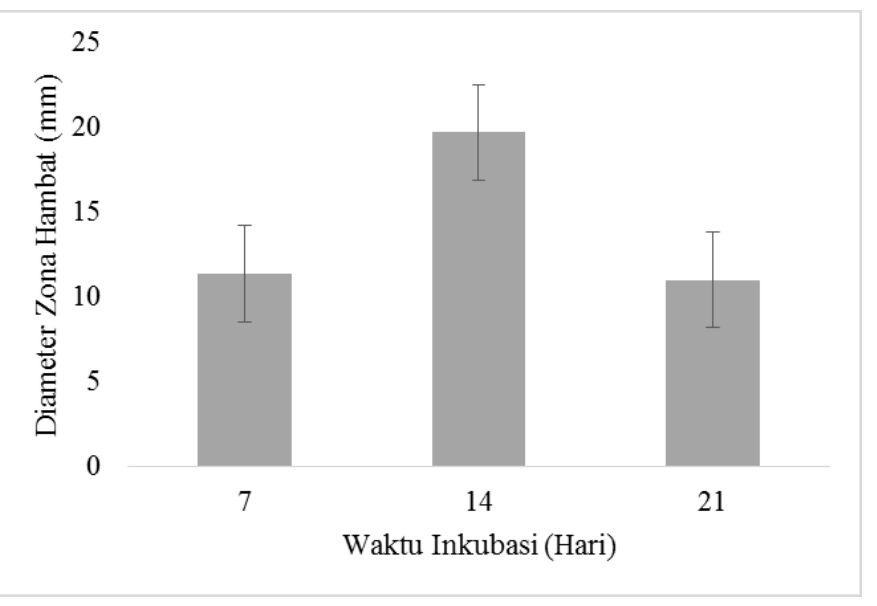

Gambar 3. Efek Periode Inkubasi terhadap Aktivitas Anti-fungi Isolat Aktinomisetes $C$ dalam menghambat $C$. Albicans

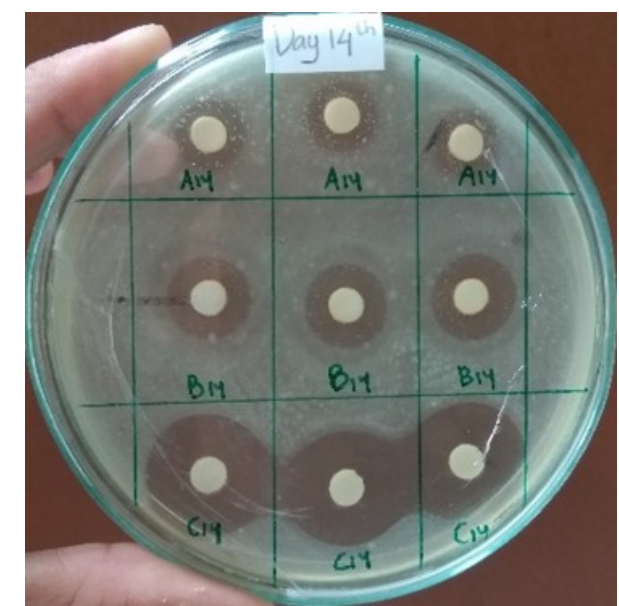

Gambar 4. Aktivitas Ekstrak Anti-fungi Isolat Aktinomisetes $\mathrm{C}$ yang menghambat $C$. albicans

\subsection{Karakterisasi Senyawa Anti-fungi}

Senyawa anti-fungi yang diekstrak menggunakan pelarut etil asetat menunjukkan aktivitas penghambatan terhadap isolat uji, dan setelah dianalisis menggunakan KLT dengan menghitung perbandingan antara jarak spot yang terbentuk terhadap jarak tempuh eluen didapatkan 4 fraksi senyawa dengan masing-masing nilai $\mathrm{Rf}$ sebesar 0,$64 ; 0,72$; 0,83; dan 0,95 (Gambar 5).

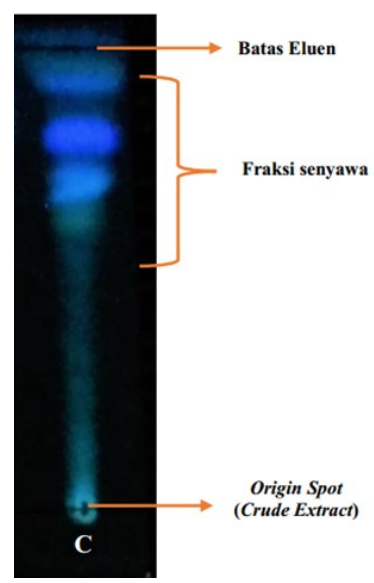

Gambar 5. Profil KLT pemisahan senyawa aktif dari ekstrak kasar isolat aktinomisetes menggunakan fase gerak (eluen) kloroform, etil asetat, dan asam asetat $(3: 3: 1 \mathrm{v} / \mathrm{v})$

\section{Pembahasan}

Berdasarkan karakter morfologi dan penggunaan sumber karbon yang telah dibandingkan dalam buku Bergey's Manual Determinative of Bacteriology, isolat aktinomisetes C yang memiliki aktivitas anti-fungi tertinggi teridentifikasi ke dalam genus Streptomyces. Identifikasi aktinomisetes hingga tingkat genus dapat meliputi beberapa karakter diantaranya, morfologi miselium, morfologi konidia, morfologi sporangia, dan struktur lainnya. Genus Streptomyces mempunyai karakter miselium dengan berbagai macam bentuk diantaranya straight, flexuous, Retiflexible, spiral dan Loop (Goodfellow et al., 2012). Menurut Holt et al., (1994), salah satu ciri khas dari genus Streptomyces adalah koloninya ditutup dengan miselium udara bebas dan hifa dikelilingi oleh selubung inti (sheath) hidrofobik mengarah dari permukaan koloni ke udara.

Seleksi isolat aktinomisetes yang berpotensi sebagai penghasil anti-fungi ditentukan berdasarkan zona penghambatannya terhadap isolat uji. Menurut Arifuzzaman et al., (2010) penentuan dapat diamati secara kualitatif dengan memberi skor dari zona hambat yang terbentuk, yaitu cukup $(+)$, potensial $(++)$, dan sangat potensial (+++). Aktivitas penghambatan oleh senyawa anti-fungi yang dihasilkan isolat aktinomisetes dapat dilihat dari pertumbuhan koloni $C$. albicans yang kurang baik, bahkan hingga tidak tumbuh sama sekali (Gambar 1). Menurut Oskay (2009), berdasarkan zona hambat yang terbentuk pada penapisan primer (Primary Screening) dapat dilanjutkan penapisan sekunder (Secondary Screening) untuk memastikan aktivitas senyawa anti-fungi yang dihasilkan oleh isolat aktinomisetes.

Diameter zona hambat dibentuk oleh aktivitas senyawa anti-fungi berbeda-beda disebabkan oleh perbedaan periode waktu inkubasi. Waktu inkubasi optimal untuk menghasilkan anti-fungi diperoleh setelah 14 hari (Gambar 3). Besar kecilnya diameter zona hambat dipengaruhi oleh berbagai hal antara lain jenis medium, jenis isolat, ketersediaan sumber karbon, pH medium, suhu inkubasi, dan lama waktu inkubasi. Ayari et al., (2016), menyatakan bahwa aktivitas anti-fungi isolat Streptomyces sp. AA13 terhadap pertumbuhan $C$. albicans dipengaruhi oleh lama waktu inkubasi, sumber karbon, dan suhu inkubasi. terdapat beberapa genus dari aktinomisetes yang mempunyai waktu maksimal untuk memproduksi senyawa metabolit dan selanjutnya akan mengalami penurunan aktivitas. Genus Streptomyces mempunyai aktivitas menghasilkan senyawa metabolit khususnya senyawa anti-fungi sebelum waktu fermentasi 14 hari. Hal tersebut sesuai dengan pernyataan Maataoui (2014), bahwa laju kinetika produksi dari senyawa 
aktif oleh Streptomyces menunjukkan terjadinya produksi maksimal antara hari ke-7 hingga ke-10. Bouras et al., (2013) juga melaporkan bahwa waktu maksimal aktivitas antimikroba oleh Streptomyces sp. PP14 diperoleh setelah 7, 8 atau 9 hari fermentasi. Dapat diambil kesimpulan bahwa produk senyawa metabolit dihasilkan pada waktu pertumbuhan optimal.

Hasil karakterisasi senyawa aktif menggunakan metode KLT diperoleh nilai $\mathrm{Rf}$ sebesar 0,64;0,72;0,83; dan 0,95 yang divisualisasi menggunakan sinar UV dengan panjang gelombang $254 \mathrm{~nm}$. Menurut Prakash et al., (2013) pemurnian secara parsial dari ekstrak kasar dari medium kultur aktinomisetes (Streptomyces rochei MSA14) melalui TLC dengan sistem pelarut yang bertingkat menunjukkan beragam spot dari suatu senyawa aktif, menunjukkan nilai Rf antara 0.22 hingga 0.99 .

\section{Kesimpulan}

Tanah perakaran tanaman mangrove Segara Anakan Cilacap merupakan salah satu habitat bakteri aktinomisetes khususnya genus Streptomyces yang berpotensi sebagai sumber anti-fungi untuk menghambat pertumbuhan $C$. albicans. Periode waktu inkubasi berpengaruh terhadap aktivitas anti-fungi yang dihasilkan oleh isolat aktinomisetes. Karakter senyawa aktif yang dihasilkan mempunyai nilai Rf beragam.

\section{Ucapan Terima Kasih}

Penelitian merupakan bagian dari hibah peningkatan kompetensi Tahun 2017. Penulis menyampaikan terima kasih kepada Dra. Dini Ryandini, M.Si. dan Dra. Dyah Fitri Kusharyati, M.P dan segenap crew Lab. Mikrobiologi Fakultas Biologi UNSOED atas bantuan dan kerja samanya selama pelaksanaan penelitian.

\section{Acuan}

Arifuzzaman, M., Khatun, M.R. dan Rahman, H. 2010. Isolation and Screening of Actinomycetes from Sundarbans Soil for Antibacterial Activity. African Journal of Biotechnology, 9(29), pp. 4615-4619.

Ayari, A., Morakchi, H., dan Djamila, K.G. 2016. Isolation of Antifungal Activity of Novel Marine Actinomycete, Streptomyces sp. AA13 Isolated from Sediments of Lake Ougeria (Algeria) Against Candida albicans. African Journal of Microbiology Reseacrh, 10(6), pp. 156-171.
Bouras, N., Meklat, A., Toumatia, O., Mokrane, S., Holtz, M.D., Strelkov, S.E.m., dan Sabaou, N. 2013. Bioactive Potential of a New Strain of Streptomyces sp. PP14 Isolated from Canadian Soil. African Journal of Microbiology Research, 7(25), pp. 3199-3208.

Brooks, G.F., Butel, J.S., dan Morse, S.A. 2004. Jawetz, Melnick, dan Adelberg's Medical Microbiology. Jakarta: Penerbit Buku Kedokteran ECG.

Brown-Elliott, B.A., Brown, J.M., Coville, P.S., dan Wallace, R.J, Jr. 2006. Clinical and laboratory Features of the Nocardia spp. Based on Current Molecular Taxonomy. Clin Microbiol Rev, 19(2), pp. 59-82.

Dewi, A.K. 2014. Aktivitas Antifungai Isolat Actinomycetes dari Sampel Pasir Gunung Merapi dengan Lama Fermentasi yang Berbeda Terhadap Candida albicans. Skripsi. Fakultas Keguruan dan IImu Pendidikan UMS: Surakarta.

Goodfellow, M., Kampfer, P., Busse, H.J., Trujillo, M.E., Suzuki, K., Ludwig, W., dan Whitman, W.B. 2012. Bergey's Manual of Determinative Bacteriology $2^{\text {nd }}$ Edition. Springer, USA.

Holt, J.G., Krieg, N.R., Sneath, P.H.A., Staley, J.T., dan Williams, S.T. 1994. Bergey's Manual of Determinative Bacteriology $9^{\text {th }}$ Edition. Lippincott Williams \& Wilkins, Philadelphia USA.

Kang, M.J., Strap, J.L. dan Crawford. 2010. Isolation and Characterization of Potent Antifungal Strains of the Streptomyces violaceusniger Clade Active Against Candida albicans. J. Ind. Microbiol. Biotechnol., 37, pp. 35-41.

Maataoui, H., Iraqui M., Jihani, S., Ibnsouda, S., dan Haggoud, A. 2014. Isolation, Characterization and Antimicrobial Activity of a Streptomyces Strain Isolated from Deterorated Wood. African Journal of Microbiology Research, 8(11), pp. 1178-1186.

Oskay, M. 2009. Antifungal and Antibacterial Compounds from Streptomyces Strains. African Journal of Biotechnology, 8(13), pp. 3007-3017.

Prakash, S., Ramasubburayan, R., P. Iyappraja., C. Kumar., C.J. Mary., A. Palavesam., dan G. Immanuel. 2013. Screening and Partial Purification of Antifungal Metaboliter from Streptomyces rochei MSA14: an Isolate from Marine Mining Soil of Southwest Coast of India. Indian Journal of Geo-Marine Sciences, 42(7), pp. 888-897. 
Purwantini, I. dan Wahyuono, S. 2004. Isolasi dan Identifikasi Senyawa Antijamur (Candida albicans) dari Kulit Buah Delima (Punica granatum L.). Majalah Farmasi Indonesia hal 10-14. Universitas Gajah Mada.

Rao, N.S.S. 2001. Soil Microbiology, Fourth Edition of Soil Microorganism and Plant Growth. USA: Science Publisher, Inc.
Sharma, H., dan Parihar, L. 2010. Antifungal Activity of Extract Obtained from Actinomycetes. Journal of Yeast and Fungal Research,1(10), pp. 197-200.

Wardana, R.S. 2016. Aktivitas Penghambatan Isolat Streptomyces dari Rizosfer Avicennia marina Kawasan Segara Anakan Terhadap Bakteri Patogen. Skripsi. Universitas Jenderal Soedirman. 